\title{
Jordens tid i spiral? - forslag til ny tidsinddeling
}

\section{Af Niels Wium}

En læser har dette lidt kontroversielle forslag til en ny geologisk tidsinddeling, der efter hans mening er mere praktisk.

Menneskets levetid på jorden har længe ligget rimeligt fast: der kunne normalt regnes med 4 generationer på 100 år. Men nu skal man vel nærmere regne med 3 generationer på 100 år?

\section{"Spiralinddeling" af tiden}

For en lægmand har historien om Jordens udvikling - og især biosfærens - været fast knyttet til videnskabens (ret flydende og historisk begrundede) valg af navne på diverse tidsperioder. Og disse tidsperioder er af forskellig størrelse, der endda jævnligt justeres.

For eksempel varer Silur ca. 30 millioner år (for 400 millioner siden), medens Kridt varer ca. 79 millioner år (for ca. 100 millioner år siden).

For at bevare udsynet set fra vores nutid foreslås i stedet en fælles tidsinddeling for geologer og eksperter i forsteninger, hvor hver ældre periode er dobbelt så lang som den tidligere og lige så lang som alle de tidligere tilsammen, det, jeg kalder en "spiralinddeling" af tiden.

En sådan tidsinddeling svarer nok (med mange undtagelser) stort set til, at vores viden om fortiden bliver mindre, jo længere tilbage vi kommer i tid. Se de 2 skemaer, hvor det ene er den øverste del af det andet. Det nye forslag sammenlignes med det eksisterende.

\section{Ny tidsinddeling}

Før den angivne "sen zero tid" kan de, der tror på "the Big Bang", venligst tilføje "zero tid", ældre end 8.200 millioner år.
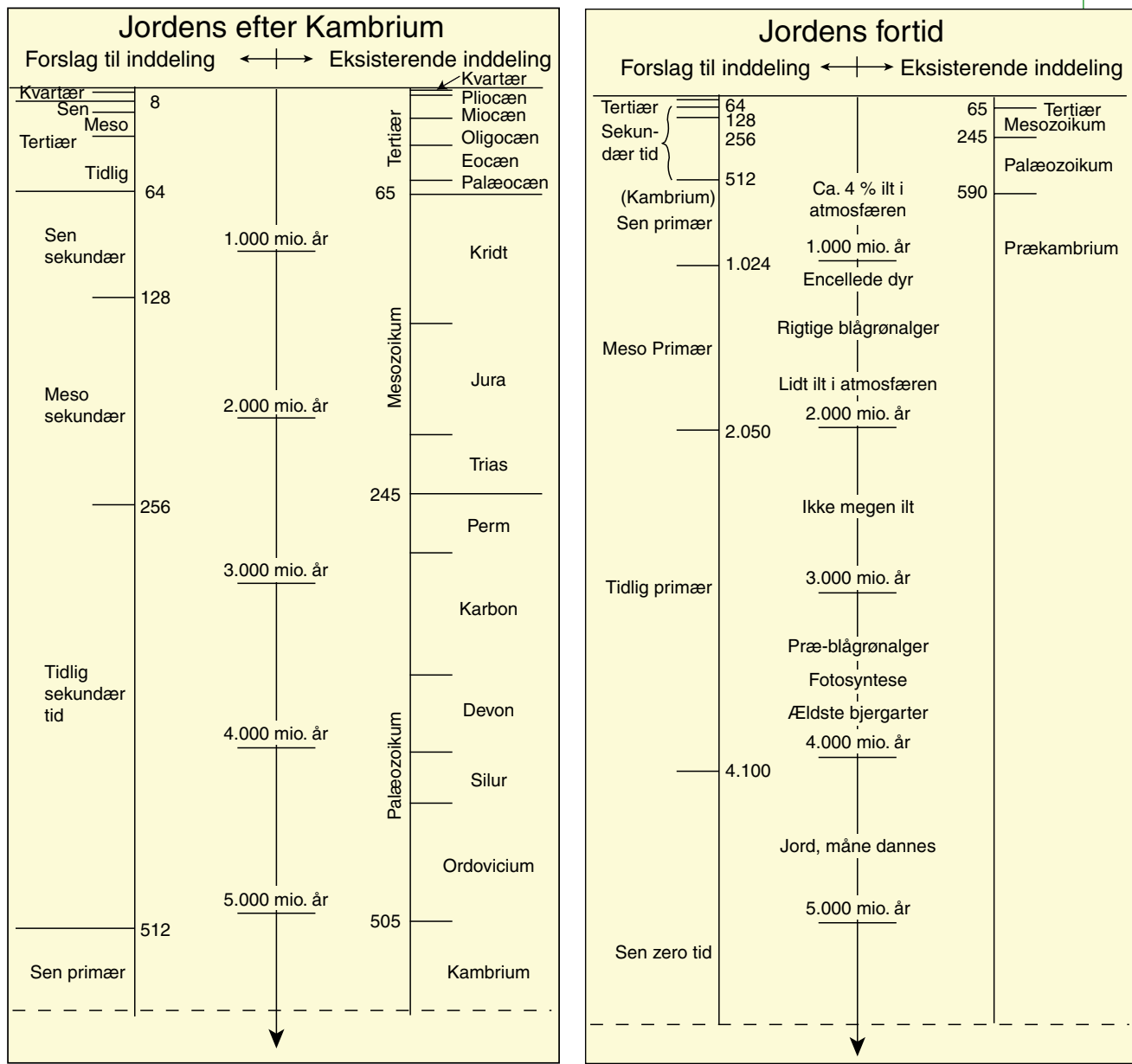

Skemaet til venstre svarer til den øverst del af skemaet til højre. (Grafik: UVH)
Af skemaerne fremgår, at forslaget medfører nogle ændringer i det tilvante:

- Det gamle Kvartær bliver sidste trediedel af den nye kvartære tid.

- Eocæn og Palæocæn slås sammen i Tertiærtiden.

- Kridttiden bliver lidt kortere (andet navn?) som sen sekundær tid.
Den nye, kvartære tid (tre-delt, i alt 8 millioner år) kan efter samme system inddeles videre således: Sextær tid (tre-delt): 125.000 år

de sidste istider med sidste istid Septiær tid (tre-delt): 15.625 år
Pentær tid (tre-delt): 1.000 .000 år

Og så videre. Ved den videre inddeling må tidens nulpunkt vedtages.
- Palæozoikum svarer nu til "tidlig sekundær tid", idet dog Kambrium overføres til "sen primær tid"

- "Primær tid" går i 3 dele, fra 4.100 millioner år til 512 millioner år før nu, rimeligt dækkende Jordens tidlige udvikling med livets oprindelse.Det er snart vigtigt med en praktisk og international tidsskala for Jordens udvikling.

\section{Vidste du:}

At du kan købe alle de tidligere, ikke-udsolgte numre (ekskl. porto 63,00 kr.)? (p.t. 62 stk.) for kun 300 kr. 